\title{
Performance Based Water Loss Management for Gweru, Zimbabwe
}

\author{
Eugine Makaya* \\ Department of Civil and Water Engineering, National University of Science and Technology, Bulawayo, Zimbabwe \\ *Corresponding author: eugine.makaya@gmail.com; eugine.makaya@nust.ac.zw
}

\begin{abstract}
Different water utilities use different performance indicators to assess their performance. Although these indicators are peculiar to particular situations, it is paramount that each indicator is applied consistently among utilities as this is good for benchmarking purposes. Besides being well documented, performance indicators have not been well reviewed from the perspective of developing countries. Furthermore, there is limited understanding of the application of performance indicators among developing countries. Therefore this paper reviewed performance indicators for physical water loss management. The African Development Bank self-assessment matrix was applied to the City of Gweru, Zimbabwe. Furthermore, the infrastructure leakage index was used to assess the performance of the water utility. The self-assessment approach showed a $62 \%$ level of implementation of NRW strategies by the city. This means that the city was poorly managing its non-revenue water. The city had an infrastructure leakage index of 9.7. This index is in Category $\mathrm{C}$ of the International Water Association physical loss matrix meaning that the city was managing its non-revenue water poorly. Therefore the city must be proactive in the management of its physical water losses as well as maintain its infrastructure consistently.
\end{abstract}

Keywords: infrastructure leakage index, non-revenue water, performance indicators, water loss management

Cite This Article: Eugine Makaya, "Performance Based Water Loss Management for Gweru, Zimbabwe." American Journal of Water Resources, vol. 5, no. 4 (2017): 100-105. doi: 10.12691/ajwr-5-4-2.

\section{Introduction}

Many developing countries throughout the world are facing a variety of water supply challenges [1]. Arid and semi-arid areas are particularly facing severe water scarcity due to rapidly growing demand for water resources [2]. Resultantly, urban water supply suffers a myriad of challenges that include intermittency and unauthorised connections [3].

Despite the challenges affecting developing countries, Africa has the least water supply and sanitation coverage than any other region in the world [2]. More than a third of Africans living in urban set-ups are currently lacking access to adequate water services and facilities [1]. New strategies for water development and management are urgently needed to avert severe national, regional and local water scarcities that will depress agricultural and industrial productivity [4].

There is considerable difference between the volumes of water transmitted and the volume of water billed to consumers [5,6], hence non-revenue water. Non-revenue water (NRW) is a measure of a utility's efficiency in terms of both operational performance and financial performance [6]. The utilities in developing countries $(30-40 \%)$ have the highest levels of NRW [7,8]. NRW has severe impacts on the efficiency of water utilities thereby affecting water customers [9]. Although it is a generalisation, non-revenue water is a good indicator of the efficiency of performance of water utilities [10].
Each year more than 32 billion cubic metres of treated water is lost through leakage from water supply systems, of which 16 billion cubic metres of treated water annually is conveyed to customers but not invoiced because of theft, poor metering, or corruption [9]. A conservative estimate of the total annual cost of non-revenue water to water utilities worldwide is 14 billion United States Dollars [11]. In some low-income countries the loss constitutes 50-60\% of total water supplied, against a global average of 35\% [11]. According to USAID and WBI [12], one hundred million more people could be supplied with enough water if half the amount of water lost was saved.

Water losses are seriously affecting performance of water utilities in developing countries [13]. Water utilities in the state of Selangor, Malaysia (1997) and Bankok, Thailand (2000) are examples where water losses affected performance [14]. Water availability challenges are exacerbated by escalating volumes of water losses and whose consequences force water utilities to fail their customers [6]. Performance Indicators (PIs) help water utilities evaluate their water losses, benchmark and measure performance set against standards and optimise investment decisions [6].

Underperformance causes water utilities to operate at low technical efficiency levels below best-practice determined by the relatively efficient ones [15]. Reflecting on the status quo, there is need for a paradigm shift to utilize water resources as efficiently as possible [5].

Managers, policymakers, regulatory agencies and financing institutions use NRW PIs to rank a utility's performance against industry standards and other water utilities. 
The objective of this paper is to review the applicability of NRW and Infrastructure Leakage Index as key performance indicators used widely in developing countries. In so doing the paper fills the knowledge gap due to the divergent views of many schools of thought. The paper further explores the self-assessment methodology for assessing the level of management of NRW [16] by the City of Gweru, Zimbabwe.

\section{Performance Indicators in Water Loss Management: Performance Assessment Systems}

Performance measurement plays key roles in assessing performances of water utilities. Therefore it is important for water utilities to adopt performance assessment systems for enhanced service delivery. Poor service delivery by water utilities is often due to poor governance and financial frameworks $[6,15]$. Thus, this notion confirms the commonly held view that Africa's water supply systems run at unacceptably low levels of technical efficiency [15]. Water utilities have to provide some service to customers daily against the backdrop of deteriorated infrastructure [6]. By assessing a utility's performance using PIs one can determine the quality of service and the utility's efficiency. Furthermore, PIs allow for the comparison of objectives, provides benchmarks among similar institutions and encourages the provision of improved services [17].

Most indicators for water loss management were developed by the International Water Association (IWA) $[18,19]$ and adopted by the American Water Works Association (AWWA), African Development Bank and Asian Development Bank. Important indicators by IWA for water loss management include the following [18]: Litres per service connection per day $(1 / \mathrm{c} / \mathrm{d})$; Litres per service connection per day per metre of pressure $(1 / \mathrm{c} / \mathrm{d} / \mathrm{m}$ pressure); and Litres per kilometre of pipeline per day $(1 / \mathrm{km} / \mathrm{d})$. A good NRW PI must be rational and easily applied [9]. It should be easily computed using readily available utility data [9].

Utilities should include standard PIs to measure performance in order to facilitate comparisons with other utilities. Tools such as decision trees are available for managers to select appropriate PIs for their utility needs and operating context [20]. On the other hand Performance Assessment Systems (PASs) are systems used by water utilities to evaluate own performance by identifying performance drivers and by measuring success in achieving their set targets [5,21].

Each institution may use a different PAS to measure performance. Poor performance results in a vicious spiral as the problems regenerate with time [5]. The performance of a water utility can be described as a low level equilibrium in which low prices result in low quality, limited service expansion, operational inefficiency and corruption, whereby stakeholder support is compromised $[5,22]$. Thus, policy should be concerned with prescriptions aimed at maximizing the efficiency of specific institutions in terms of the operators' efficiency, regulators' competence and endowments.

The most widely used water loss management indicators are shown in Table 1. AWWA [23] classified the levels as basic, intermediary and detailed.

The "Basic" level is the first level of indicators that provides a general management overview of the efficiency and effectiveness of a water supply institution. The "Detailed" level represents indicators providing the greatest and specific detail but are still relevant to the top management.

Several performance indicators are recognised by many water management institutions world-over. However, the traditional PIs for real losses were chosen on the backdrop of the simplicity of calculation, country norms, data availability for the calculation, or even on the basis of producing the best performance impression [24].

Performance indicators provided in the Manual of Best Practice of IWA [17] which are used to compare the performance of water losses management are: water losses and real losses as a percentage of system input volume (SIV), water losses per house connection, water losses per $\mathrm{km}$ of mains per day (density of connections less than 20 per $\mathrm{km}$ of mains) and the Infrastructure Leakage Index (ILI).

Following, are the generally applied water loss management systems PIs.

\subsection{NRW as an Indicator}

\subsubsection{Expressing NRW as a Percentage}

Percentage NRW is the most widely used PI for evaluating water losses $[6,25,26]$. It has been widely used to measure performance and system efficiency. That means citizen satisfaction with urban service delivery is closely related to the actual performance of the services with respect to the initial expectations about the services [18].

Table 1. IWA Recommended Performance Indicators

\begin{tabular}{|l|l|l|l|}
\hline \multicolumn{1}{|c|}{ Function } & Level & \multicolumn{1}{c|}{ Performance Indicator } & \multicolumn{1}{|c|}{ remarks } \\
\hline Financial: NRW by volume & Basic & $\begin{array}{l}\text { Volume of NRW as \% of system } \\
\text { input volume }\end{array}$ & Can be calculated from simple water balance \\
\hline Financial: NRW by cost & Detailed & $\begin{array}{l}\text { Value of NRW as \% of annual cost of } \\
\text { running system }\end{array}$ & Allows different unit cost for NRW components \\
\hline Inefficiency of use of water resources & Basic & $\begin{array}{l}\text { Real loss as \% of system input } \\
\text { volume }\end{array}$ & $\begin{array}{l}\text { Unsuitable for assessing efficiency of } \\
\text { management of distribution system }\end{array}$ \\
\hline Operational: Real losses & Basic & $\begin{array}{l}\mathrm{M}^{3} / \text { service line/day, when system is } \\
\text { pressurised }\end{array}$ & Best traditional basic performance indicator \\
\hline Operational: Real Losses & Detailed & Infrastructure leakage index & Ratio of CARL to UARL \\
\hline
\end{tabular}

(Adapted from [27]). 
Non-revenue water has traditionally been expressed as a percentage of input volume [18]. Although this is preferable to setting no targets at all, percentage of input volume is a misleading PI because it favours utilities with high consumption, low pressure, and intermittent supply [24]. Despite percentage NRW being recommended as an elementary financial indicator, its main disadvantage is that it is affected by consumption patterns independent of the utility's water loss management [26]. In addition, it does not differentiate between physical losses and commercial losses. The other disadvantage is that the indicator still does not take operating pressure into account [8].

Although the IWA no longer recommends using the percentage of system input as an indicator of real losses, it is still used as one of the key PIs in the United Kingdom [24]. Nonetheless, NRW as a percentage of input is sometimes useful for its "shock value"; a high result spurs for a utility to resume studies of the network's operational performance [9]. Furthermore, it is also useful as a measure of the utility's year-on-year financial performance, as long as the measurement principles are consistent [7]. Therefore, NRW should be represented as the value and not the quantity of water lost.

\subsubsection{NRW Percentage by Volume}

Since consumption normally makes up a very significant part of SIV or water supplied for most systems and subsystems, this severely compromises the use of percentages by volume as a suitable PI for NRW and its components $[28,29]$. Computation of percentage by volume is traditional and usually a simple initial step. However, the best simple traditional real losses PIs are "per service connection" or "per km of mains" and they should be accompanied by an estimate of average pressure [19]. Furthermore, NRW percentage by volume does not account for different valuations of components of $\mathrm{NRW}$ or the cost of running the system [19].

A better financial PI for NRW is percentage by cost, which calculates the cost of each of the three principal components of NRW (Unbilled Authorised Consumption, Apparent Losses and Real Losses) by attributing different monetary valuations (per cubic metre) to each of these NRW components, and dividing by the operating cost of running the system [19]. However, challenges due to the use of percentages by volume as operational PIs for NRW and its components are extensively published [18,26]. Besides percentage NRW, infrastructure leakage index is an operational PI to be reviewed.

\subsection{Infrastructure Leakage Index}

Infrastructure Leakage Index (ILI) determines the overall infrastructure management performance to be assessed independent of the influence of current operating pressure [24]. The ILI was developed to address the lack of an objective benchmarking indicator [8,29]. The ILI and other recommended NRW and physical loss PIs based on the IWA's PIs for water supply services are shown in Table 2.

The ILI is a new PI for real losses; a ratio of current annual real losses to system-specific unavoidable annual real losses $[8,30]$.

$$
\mathrm{ILI}=\mathrm{CARL} / \mathrm{UARL}
$$

where CARL is the Current Annual Real Loss and UARL is Unavoidable Annual Real Loss.

The ILI is an excellent indicator of physical losses, which takes into account how well a network is managed [31]. It is more applicable in networks where NRW is relatively low, for example below $20 \%$, as the ILI can help to identify areas that can be improved on [32].

UARL can be used reliably to predict the lowest technical annual real losses for any combination of mains length, number of connections, customer meter location at current operating pressures, assuming that the system is in good condition and there are no financial or economic constraints [8]. Using existing knowledge and experience, UARL can be computed for any system in excess of five thousand service connections, density of connections greater than 20 per $\mathrm{km}$ mains, and operating pressure between $25-100$ metres [8,24].

Since 1999, the UARL formula has proved to be robust in predicting the lowest threshold of real losses in best performing utilities [28]. An ILI index of 1.0 indicates that current annual real losses (CARL) are equal to unavoidable annual real losses (UARL) and the water utility is operating at the technically low level of leakage possible, a very uncommon possibility [29]. Limited data from water utilities who were the early adopters of the AWWA/IWA water audit methodology indicates that ILI values typically fall in the range of $1.5-2.5[8,17]$.

The physical loss target matrix showing the expected level of ILI and physical losses in litres/capita/day from utilities in countries at differing levels of network pressure is shown in Table 2.

Table 2. Physical Loss Target Matrix

\begin{tabular}{|c|c|c|c|c|c|c|c|}
\hline \multirow{2}{*}{\multicolumn{2}{|c|}{$\begin{array}{l}\text { Technical Performance } \\
\text { category }\end{array}$}} & \multirow{3}{*}{$\begin{array}{c}\text { ILI } \\
1-2\end{array}$} & \multicolumn{5}{|c|}{$\begin{array}{l}\text { Physical Losses[litres/connection/day] } \\
\text { (When the system is pressured) at an average of }\end{array}$} \\
\hline & & & \multirow[t]{2}{*}{$10 \mathrm{~m}$} & \multirow{2}{*}{$\begin{array}{l}20 \mathrm{~m} \\
<50\end{array}$} & \multirow{2}{*}{$\begin{array}{ll}30 \mathrm{~m} \\
<75\end{array}$} & \multirow{2}{*}{$\begin{array}{ll}40 \mathrm{~m} \\
<100\end{array}$} & \multirow{2}{*}{$\begin{array}{ll}50 \mathrm{~m} \\
<125\end{array}$} \\
\hline \multirow{4}{*}{ 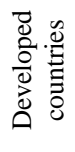 } & A & & & & & & \\
\hline & B & $2-4$ & & $50-100$ & $75-150$ & $100-200$ & $125-250$ \\
\hline & C & $4-8$ & & $100-200$ & $150-300$ & $200-400$ & $250-500$ \\
\hline & $\mathrm{D}$ & $>8$ & & $>200$ & $>300$ & $>400$ & $>500$ \\
\hline \multirow{4}{*}{ 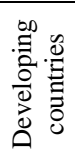 } & A & $1-2$ & $<50$ & $<100$ & $<150$ & $<200$ & $<250$ \\
\hline & B & $2-4$ & $50-100$ & $100-200$ & $150-300$ & $200-400$ & $250-500$ \\
\hline & $\mathrm{C}$ & 4-8 & $100-200$ & $200-400$ & $300-600$ & $400-800$ & $500-1000$ \\
\hline & $\mathrm{D}$ & $>8$ & $>200$ & $>400$ & $>600$ & $>800$ & $>1000$ \\
\hline
\end{tabular}

(Adapted from [12]). 
The ILI indicators are provided as crude guidelines and should not be taken to be restrictive limits $[33,34]$. However, for the greater parts of Africa and Asia, very high ILI values are a norm and the limits given in Table 2 are subdued [34]. The main purpose of the ILI indicator is to help identify areas where leakage/losses are abnormally high to ensure that action is taken in the most appropriate areas [8].

To guide further network development and improvement, utility managers could use a matrix with the following categories [12]. For Category A, the ILI value ranges 1-2, representing good performance with respect to real losses [8]. Further loss reduction may be uneconomic and careful analysis is needed to identify cost-effective improvements. Category B indicates that there is potential for improvement. The category entails good pressure management, better active leakage control and better maintenance. Category $\mathrm{C}$ denotes poor performance. This class is only tolerable when water is plentiful and cheap, and there is need to intensify NRW reduction effort. Category D connotes bad performance and the utility is using resources inefficiently and NRW reduction programmes are imperative.

\section{Study Area}

The case study of Irvine middle density suburb of Gweru, Zimbabwe was considered. Irvine was chosen because it is a standalone district metered area and had the least water supply interruptions. Gweru city has a total population of about 157,000 [35]. Gweru City Council is responsible for water supply in the city. Irvine has about 390 residential stands, all connected to municipal water supply system. Poor water supply infrastructure management is the major water related challenge the city faces [36].

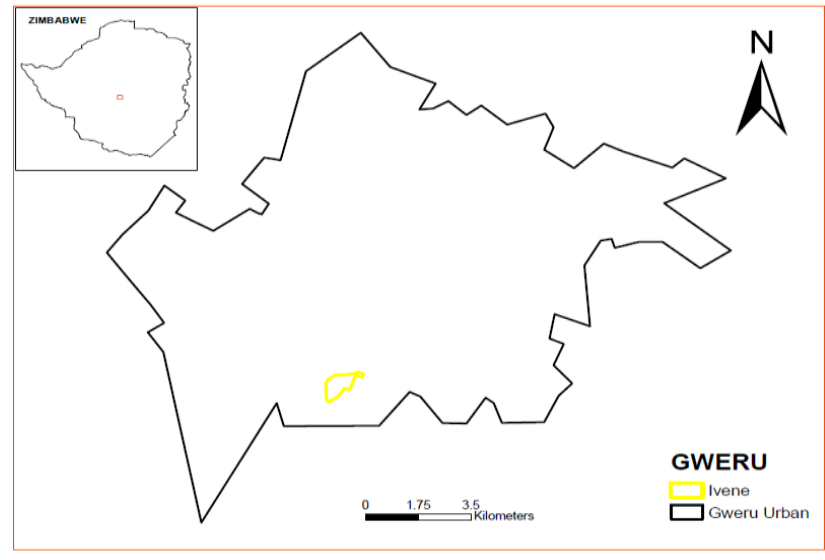

Map 1. Map of Gweru Showing Location of Irvine

\section{Materials and Methods}

\subsection{NRW Performance Assessment}

The level of management of NRW in Irvine, Gweru was done following the self-assessment methodology proposed by the International Water Association [16]. The self-assessment matrix of non-revenue water management for the best practice was developed by Africa Development Bank [37] and adapted from IWA [12]. The proposed assessment parameters for a utility's NRW management are shown in Table 3. Table 3 presents the enabling factors for each of the strategies currently implemented and proposed respectively.

For the matric shown in Table 3, each level has a range of scenarios ("1" is poor and "5" is excellent) which describes the implementation level in a given area. The City of Gweru water managers and the author used the matric to assess the city-wide level of management of NRW.

Table 3. NRW Management Assessment Matrix

\begin{tabular}{|c|c|c|c|c|}
\hline \multicolumn{5}{|c|}{ Management Level } \\
\hline 1 (Poor) & 2 & 3 & 4 & 5 (Excellent) \\
\hline $\begin{array}{l}\text { No monitoring of NRW } \\
\text { indicators. } \\
\text { No NRW management } \\
\text { strategy. }\end{array}$ & $\begin{array}{l}\% \text { NRW } \\
\text { Monitored. } \\
\text { Water } \\
\text { balance is } \\
\text { available. } \\
\text { No NRW } \\
\text { Management strategy. }\end{array}$ & $\begin{array}{l}\% \text { NRW monitored. } \\
\text { Water balance available. } \\
\text { Some actions are undertaken } \\
\text { to reduce commercial or } \\
\text { physical losses but without } \\
\text { NRW management strategy }\end{array}$ & $\begin{array}{l}\text { Some actions are undertaken } \\
\text { to reduce commercial or } \\
\text { physical losses but without } \\
\text { NRW management strategy. }\end{array}$ & $\begin{array}{l}\text { IWA Water balance available and } \\
\text { regularly updated. } \\
\text { Physical and commercial } \\
\text { Losses' performance indicators } \\
\text { monitored. } \\
\text { Regular NRW reduction activities as } \\
\text { per a comprehensive NRW } \\
\text { management strategy. } \\
\text { Sufficient budget for NRW } \\
\text { management. }\end{array}$ \\
\hline
\end{tabular}

\subsection{Real Loss Computations Using Night Flow Analysis Method}

The Night Flow analysis method computes flow in a network when the water demand is at its lowest [30]. The minimum night flow approach was used to determine water leakage in the water distribution system. Flow loggers were installed and flow data recorded from the $9^{\text {th }}$ of May 2016 to $13^{\text {th }}$ May 2016.

Equations (2) through Equation (4) were used in computing real losses [38].
Expected Minimum Night Flow

$=$ Background losses + Normal night use.

Excess Night Flow (ENF)

= Measured MNF - Expected Minimum Night Flow.

Leakage $\left(\mathrm{m}^{3} /\right.$ month $)$

$=\operatorname{ENF}\left(\mathrm{m}^{3} / \mathrm{hr}\right) \times($ hour $/$ day factor $) \times 30$ days $/$ month.

Thus, equation (4) represents the real losses in a water supply system. 


\section{Results and Discussion}

\subsection{Self-assessment for NRW Management}

A result of 3.1 out of 5 was obtained from the strategies used by Gweru city following the ranking of individual strategies. This represents $62 \%$ implementation of NRW strategies. Thus the outlined methodology can be effectively used to assess the level of non-revenue water management of a water utility. Such an indicator would prompt the water utility to embrace other water loss management approaches such as active monitoring and leakage management.

\subsection{ILI Computation}

Minimum night flows

The results for the minimum night flow for the period $9^{\text {th }}-13^{\text {th }}$ May 2016 are shown in Table 4.

Table 4. Five-day MNF Values $\left(9^{\text {th }}\right.$ May $2016-13^{\text {th }}$ May 2016)

\begin{tabular}{|c|c|}
\hline Day & MNF $\left(\mathrm{m}^{3} / \mathrm{hr}\right)$ \\
\hline 1 & 12.0 \\
\hline 2 & 12.0 \\
\hline 3 & 11.0 \\
\hline 4 & 13.0 \\
\hline 5 & 13.0 \\
\hline Average & 12.2 \\
\hline
\end{tabular}

Total NRW = Annual SIV - Annual Billed Consumption

$\mathrm{NRW}=250421-109813=140608 \mathrm{~m}^{3} /$ year

Real loss $=\mathrm{ENF} \mathrm{x}$ hour / day factor $\mathrm{x} 365$ days / year

$=9.13 \times 24 \times 365=79979 \mathrm{~m}^{3} /$ year

Apparent losses $=\mathrm{NRW}-$ Real Losses

$\mathrm{AL}=140608-79979=60629 \mathrm{~m}^{3} /$ year

$\mathrm{UARL}=[(18 \mathrm{xLm})+(0.8 \mathrm{xNs})+(25 \mathrm{xLp})] \mathrm{xP}$

where $\mathrm{Lm}$ is length of mains $(\mathrm{km})$; $\mathrm{Nc}$ is number of service connections; Lp is total length of private pipe, property boundary to customer meter $(\mathrm{km})$; and $\mathrm{P}$ is average pressure $(\mathrm{m})$.

Thus,

$$
\begin{aligned}
\text { UARL } & =[(18 \times 7.9979)+(0.8 \times 384)+(25 \times 0)] \times 50 \\
& =22558 \text { litres } / \text { day } \\
& =8234 \mathrm{~m}^{3} / \text { year }
\end{aligned}
$$

Thus

$$
\begin{aligned}
\mathrm{ILI} & =\mathrm{CARL} / \mathrm{UARL} \\
& =79979 / 8234 \\
& =9.7 .
\end{aligned}
$$

Thus, the ILI for Irvine falls in the range 8-16, category $\mathrm{C}$ of the Technical Performance Category for developing countries [39] meaning that there is poor real loss management in the City of Gweru.

\section{Conclusions}

Therefore performance based water loss management plays a pivotal role in the assessment of the efficiency of water utilities. However, the comparison of performances between utilities should not be based entirely on percentage of SIV. IWA Manual of Best Practice with litres/connection/day gives a more accurate picture hence a better indicator.

The implementation of NRW management strategies by City of Gweru is just intermediate, to minimize losses to the acceptable values, and as such the city should up-scale their NRW management initiatives. The City of Gweru's ILI is too high and more effort should be channelled towards NRW reduction. Thus the two indicators, NRW and ILI, confirm the need for the city to manage water losses and maintain their infrastructure proactively.

\section{Acknowledgements}

The City of Gweru and an anonymous assistant are acknowledged for the technical support to this study.

\section{References}

[1] Doe H. W. 2007. Assessing the Challenges of Water Supply in Urban Ghana: The case of North Teshie. Master's Thesis, Department of Land and Water Resources Engineering, Royal Institute of Technology (KTH) Stockholm, Sweden.

[2] Lehmann 2010. Challenges to Water Pricing in Developing Countries: The Case of Lima, Peru Helmholtz Centre for Environmental Research - Germany

[3] Rizzo A. 2000. Leakage Control and Unaccounted for Water Analysis. International Symposium on Efficient Water Use in Urban Areas: Innovative Ways of Finding Water for Cities. Kobe, Japan, UNEP-IETC.

[4] Rosegrant M. W. 1997 Water Resources in the twenty first Century: Challenges and Implications for Action: Food, Agriculture and The Environment Discussion Paper 20. International Food Policy Research Institute, Washington DC.

[5] Baietti A. Kingdom, W. \& Van Ginneken M. 2006. Characteristics of well performing Public Water Utilities: World Bank Water Supply and Sanitation working Note No. 9.

[6] Kingdom B. Liemberger R. \& Marin P. 2006. The Challenge of Reducing Non-Revenue Water (NRW) in Developing Countries. How the Private Sector Can Help: A Look at Performance-Based Service Contracting, Washington DC, The World Bank.

[7] Makaya E. \& Hensel O. 2014 Water distribution systems efficiency assessment indicators-Concepts and Application. International Journal of Science and Research, Volume 3 Issue 7, July 2014, 219-229.

[8] Winarni W. 2009. Infrastructure Leakage Index (ILI) as Water Losses Indicator. Civil Engineering Dimension, Vol. 11 (2).

[9] Farley M. Wyeth G. Ghazali Z. Istandar A. \& Singh S. 2008. The Manager's Non-Revenue Water Handbook: A Guide to Understanding Water Losses, Washington DC, USA.

[10] Farley M. 2003. Non-revenue water - International Best Practice for Assessment, Monitoring and Control Annual CWWA Water, Wastewater and Solid Waste Conference. Atlantis, Paradise Island, Bahamas.

[11] SIWI. 2008. Making Water a Part of Economic Development: The Economic Benefits of Improved Water Management and Services. Stockholm, Sweden, Stockholm International Water Institute.

[12] USAID \& WBI. 2010. The Manager's Non-Revenue Water Handbook for Africa: A guide to understanding Water Losses, Washington DC, Development Alternatives Inc (DAI).

[13] Dighade, R. R. Kadu, M. S.. \& Pande A.M. 2014. Challenges in Water Loss Management of Water Distribution Systems in 
Developing Countries. International Journal of Innovative Research in Science, Engineering and Technology Vol. 3, Issue 6, June 2014, 13838-13846.

[14] Pearson D. \& Trow S. 2005. Calculating Economic Levels of Leakage, Conference Proceedings, IWA Leakage 2005 Conference in Halifax, Nova Scotia, Canada.

[15] World Bank. 2002. Policy Research Working Paper 2890 Sector Organization, Governance, and the Inefficiency of African Water Utilities.

[16] IWA. 2008. IWA water balance with modified Apparent Loss component: IWA Apparent Loss Manual, London, United Kingdom, IWA Publishing.

[17] Alegre H. Hirner W. Baptista J.M. \& Parena R. 2000 Performance Indicators for Water Supply Services. IWA Manual of Best Practice. ISBN 900222272.

[18] Abebaw D. Tadesse F. \& Mogues T. 2010. Access to Improved Water Source and Satisfaction with Services Evidence from Rura Ethiopia. IFPRI Discussion Paper 01044. International Food Policy Research Institute, Washington DC.

[19] Lambert A. 2003. Assessing non-revenue water and its components: A practical approach. Water21, Vol. (Aug.), 51-52.

[20] Mutikanga H.E. 2012. Water losss management strategies. Tools and Methods for developing Countries. PhD Thesis CRC Press/Balkema, The Netherlands.

[21] Coelli T. Estache A. Perelaman S. \& Trujillo L. 2003. A Primer on Efficient Measurement for Utilities and Transport Regulators, World Bank Institute, Washington, D.C, USA.

[22] Rizzo A. Pearson D. Stephenson M. \& Harper N. 2004 Apparen water loss control: A practical approach. IWA Water Loss Task Force Water21, Vol. 6(3).

[23] AWWA 2003. Committee report: Applying worldwide BMPs in water loss control. Journal AWWA, 95 (8), 65-79.

[24] Lambert A. O. Brown T. G. Takizawa M. \& Weimer D. 1999. "A review of performance indicators for real losses from water supply systems." Aqua-Journal of Water Services Research and Technology, 48 (6), 227-237.

[25] Balkaran C. \& Wyke G. 2002. Managing Water Loss: Strategies for the Assessment, Reduction and Control of Non-Revenue Water (NRW) in Trinidad and Tobago.

[26] Lambert A. \& Taylor R. 2010. Water Loss Guidelines, New Zealand, Water New Zealand.
[27] Water Loss Group. 2005. IWA Task Force: Best Practice Performance Indicators for Non-Revenue Water and Water Loss Components: A Practical Approach, Halifax.

[28] Lambert A. O. 2002. International report: Water losses management and techniques. Water Science and Technology: Water Supply Vol. 2 (4), 1-20.

[29] Liemberger R. Brothers K. Lambert A. Mckenzie R. S. Rizzo A. \& Waldron T. 2007 Water Loss Performance Indicators: Proceedings of IWA Specialised Conference Water Loss 23th26th September, 2007. Bucharest-Cyprus, London, IWA Publishing.

[30] McKenzie R.S. Wegelin W.S. Meyer N. \& Buckle H. 2002. United Nations Habitat and Rand Water: Water Demand Management Cookbook, Pretoria, South Africa.

[31] Liemberger R. 2002. Do You Know How Misleading the Use of Wrong Performance Indicators can be? IWA Specialised Conference, Leakage Management - A Practical Approach, Cyprus, November 2002, Conference Proceedings, ISBN 9963875904.

[32] Frauendorfer R. \& Liemberger R. 2010. The issues and challenges of reducing non-revenue water. Mandaluyong City, Philippines: Asian Development Bank, 2010

[33] Makaya E. 2016. Water loss management strategies for developing countries. Understanding the dynamics of water leakages. PhD Thesis, University of Kassel, Germany.

[34] Simbeye I. 2010. Managing Non-Revenue Water. NRWSourcebook for Trainers. WAVE Pool. InWEnt.

[35] CSO 2012. Zimbabwe Population Census Provincial Report Midlands (2012). Zimbabwe National Statistics Agency, Harare.

[36] Matsa M. 2012. Urban Services Delivery in Limbo: A Provisional Assessment of Gweru's Water Supply System. Journal of Environmental Science and Engineering A1 (2012) 993-1002.

[37] Africa Development Bank. 2011. Self-Assessment Matrix on NonRevenue Water. Tunis Belvédère, Tunisia, African Development Bank

[38] Fanner P. 2004. Assessing Real Losses, including Componen Analysis and Economic Considerations: A Practical Approach. Water21 Article No 6, IWA Publishing, London.

[39] Liemberger R. 2005. Real Losses and Apparent Losses and the new W392 Guidelines from Germany. Paper presented at the International Water Association Specialist Workshop, Radisson Resort, Gold Coast, Queensland Australia. 24 February 2005. 